\title{
SISTEM INFORMASI PENGAJUAN JUDUL SKRIPSI SECARA ONLINE UNTUK MENCEGAH PENYEBARAN VIRUS COVID-19
}

\author{
Zulkifli ${ }^{1)}$ \\ 1) Program Studi Informatika, Fakultas Ilmu Komputer, Universitas Almuslim Bireuen \\ e-mail: zulladasicupak@gmail.com
}

\begin{abstract}
[Information System for Submission of Thesis Title Online to Prevent the Spread of the Covid-19 Virus] The Covid-19 pandemic has caused changes in people's behavior, one of which is in the education sector. During the pandemic, all educational institutions in Indonesia implemented online learning policies to anticipate the transmission of the Covid-19 virus. Various application platforms to support online learning activities are currently widely available, both provided by well-known companies, by the government and the educational institutions themselves. For example, universities are currently required to apply LMS (Learning Management System) technology for online lectures. However, currently not many educational institutions such as universities have also implemented an application platform for the needs of the educational administration process. When in fact it is also considered necessary because if this system does not exist, then direct contact between students and the administration still cannot be limited. Therefore, in this study, the development of an application platform that is able to support the implementation of administrative activities in this case is the submission of student thesis titles online. The system development method used is the prototype development method. The results obtained are that the system developed is in accordance with what is needed. However, for further research, it is hoped that there will be a system development for a wider scale that covers the entire process of administrative activities in the Almuslim University environment.
\end{abstract}

Keywords: Expert System; K-Means Clustering; Epilepsy; PHP; MySQL.

\begin{abstract}
Abstrak
Pandemi Covid-19 menyebabkan perubahan perilaku masyarakat, salah satunya pada sektor pendidikan. Selama masa pandemi seluruh instansi pendidikan di Indonesia menerapkan kebijakan pembelajaran daring untuk mengantisipasi penularan virus Covid-19. Berbagai platform aplikasi sebagai pendukung kegiatan pembelajaran daring saat ini banyak tersedia, baik disediakan oleh perusahaan ternama, oleh pemerintah maupun instansi pendidikan itu sendiri. Contohnya seperti perguruan tinggi yang saat ini memang diwajibkan menerapkan teknologi LMS (Learning Management System) untuk proses perkuliahan secara daring. Namun saat ini belum banyak instansi pendidikan seperti perguruan tinggi juga menerapkan suatu platform aplikasi untuk kebutuhan proses administrasi pendidikan. Padahal sebenarnya itu juga dianggap perlu dikarenakan apabila sistem ini tidak ada, maka kontak secara langsung antara mahasiswa dengan pihak administrasi masih belum bisa dibatasi. Oleh karena itu dalam penelitian ini dilakukan pengembangan suatu platform aplikasi yang mampu mendukung pelaksanaan kegiatan administrasi dalam kasus ini adalah pengajuan judul skripsi mahasiswa yang dilakukan secara daring. Metode pengembangan sistem yang digunakan adalah metode pengembangan prototype. Adapun hasil yang didapatkan yaitu sistem yang dikembangkan sudah sesuai dengan yang dibutuhkan. Namun untuk penelitian selanjutnya, diharapkan adanya pengembangan sistem untuk skala yang lebih luas yang mencakup seluruh proses kegiatan administrasi yang ada di lingkungan Universitas Almuslim.
\end{abstract}

Kata Kunci: Covid-19; Information Systems; Submission of Thesis Title; PHP; MySQL. 


\section{Pendahuluan}

Pandemi Covid-19 yang terjadi saat ini banyak membawa perubahan perilaku masyarakat dari berbagai sektor kehidupan (Livana, Suwoso, Febrianto, Kushindarto, \& Aziz, 2020; Siahaan, 2020). Salah satunya pada sektor pendidikan dimana di berbagai wilayah di Indonesia dengan kasus penyebaran Covid-19 yang tinggi, maka pemerintah setempat memberlakukan kebijakan belajar dari rumah (Nurkholis, 2020; Purwanto et al., 2020). Dalam hal pelaksanaan pembelajaran, saat ini sudah banyak hadir platform yang disediakan oleh berbagai perusahaan seperti Google yang menyediakan Google Classroom, Zoom yang menyediakan aplikasi belajar online serta berbagai aplikasi lainnya untuk mendukung pembelajaran daring baik yang gratis maupun berbayar dengan fitur premium (Fajrillah et al., 2020; Hapsari \& Pamungkas, 2019; Herliandry, Nurhasanah, Suban, \& Kuswanto, 2020).

Sama halnya dengan proses pembelajaran, proses administrasi di suatu satuan pendidikan juga dibutuhkan suatu aplikasi yang dapat mendukung kebijakan penanganan penyebaran Covid19 (Nuari, 2014). Saat ini banyak instansi pendidikan yang belum mampu menyiapkan suatu platform aplikasi yang mampu mengakomodir proses administrasi pendidikan (Rahardja, Aini, \& Zuliana, 2016; Suhardi \& Hariawan, 2020). Misalnya Universitas Almuslim secara umum yang sudah menerapkan LMS untuk proses nelajar mengajar secara daring, namun belum menggunakan platform aplikasi khusus untuk menjalankan proses administrasi perkuliahan yang mampu membatasi bertemunya mahasiswa dengan pihak administrasi kampus (Sulistiyarini \& Sabirin, 2018).

Skripsi adalah karya tulis ilmiah mahasiswa, yang merupakan kulminasi proses berfikir ilmiah sesuai dengan disiplin ilmunya, yang disusun untuk memenuhi persyaratan memperoleh gelar sesuai dengan keilmuannya (Gunawati, 2005). Sebelum menyusun sebuah skripsi ada beberapa alur atau langkah yang harus ditempuh, antara lain: mahasiswa mengajukan judul kepada tim pemeriksa, lalu bertanya secara langsung kepada admin prodi untuk memverifikasi kesamaan/tidak judul yang diajukan, apabila judulnya tidak sama mahasiswa memulai bimbingan proposal dengan dosen dari tim pemeriksa sampai selesai sehingga bisa mendaftar untuk mengikuti seminar proposal.

Sistem pengajuan judul skripsi di Fakultas Ilmu Komputer selama ini masih dilakukan secara manual, mahasiswa tidak dapat mengetahui kesamaan judul dengan cepat, serta harus bertemu langsung dengan dosen untuk melakukan proses bimbingan proposal. Untuk mengatasi permasalahan tersebut, perlu dirancang sebuah sistem pengajuan judul skripsi, yang dapat membantu menyelesaikan permasalahan yang dihadapi dalam proses pengajuan judul skripsi di Fakultas Ilmu Komputer saat ini dengan menerapkan teknologi informasi.

\section{Metode}

A. Metode dan Tahapan Penelitian

Metode yang digunakan dalam pengumpulan data antara lain:

1. Observasi (pengamatan data di lapangan)

Yaitu pengumpulan data dengan melakukan pengamatan secara langsung untuk memperoleh informasi tentang prosedur yang berlaku dalam pelaksanaan sistem yang sedang berjalan.

2. Library Lisearch (Studi Kepustakaan)

Dalam penelitian ini, penulis mencari dan mempelajari buku-buku, jurnal-jurnal, artikel-artikel laporan penelitian dan bahan-bahan yang diperoleh dari internet yang berkaitan dengan topic pembahasan yang dapat memberikan informasi dalam pembuatan sistem informasi tentang permasalahan yang terkait.

3. Wawancara

Wawancara dilakukan dengan pihak terkait menyangkut dengan prosedur sehingga sistem yang diimplementasikan sesuai dengan yang diharapkan oleh pengguna.

B. Metode Pengembangan Sistem

Adapun metode pengembangan sistem yang digunakan dalam penelitian ini yaitu metode prototype. Dalam metode ini dilakukan pengembangan perangkat lunak yang berorientasi kepada kebutuhan pengguna. Dalam metode ini, pengembangan dibagi menjadi beberapa tahapan, dimana pada tahapan pertama akan dilakukan perancangan hingga pengujian yang melibatkan user untuk menilai sejauh mana keseuaian yang telah dicapai. Pada tahapan tersebut juga dilakukan perbaikan-perbaikan apabila ditemukan bug dan kesalahan impelementasi. Setelah tahap tersebut selesai dikerjakan, maka langkah selanjutnya yaitu memulai tahapan berikutnya dengan proses yang sama dengan tahap sebelumnya, sehingga pada akhirnya didapatkan suatu sistem yang final yang siap untuk digunakan. 


\section{Hasil dan Pembahasan}

A. Perancangan Sistem

Tujuan dari perancangan sistem adalah untuk memenuhi kebutuhan user (pemakai) mengenai gambaran yang jelas tentang perancangan sistem yang akan dibuat serta diimplementasikan. Perancangan sistem adalah suatu upaya untuk membuat suatu sistem yang baru atau memperbaiki sistem yang lama secara keseluruhan atau memperbaiki sistem yang telah ada. Desain sistem secara umum mengidentifikasikan komponenkomponen sistem informasi yang akan didesain secara terinci. Desain terinci dimaksudkan untuk pemrogram komputer dan ahli teknik lainnya yang akan mengimplementasikan sistem.

1. Diagram Kontek

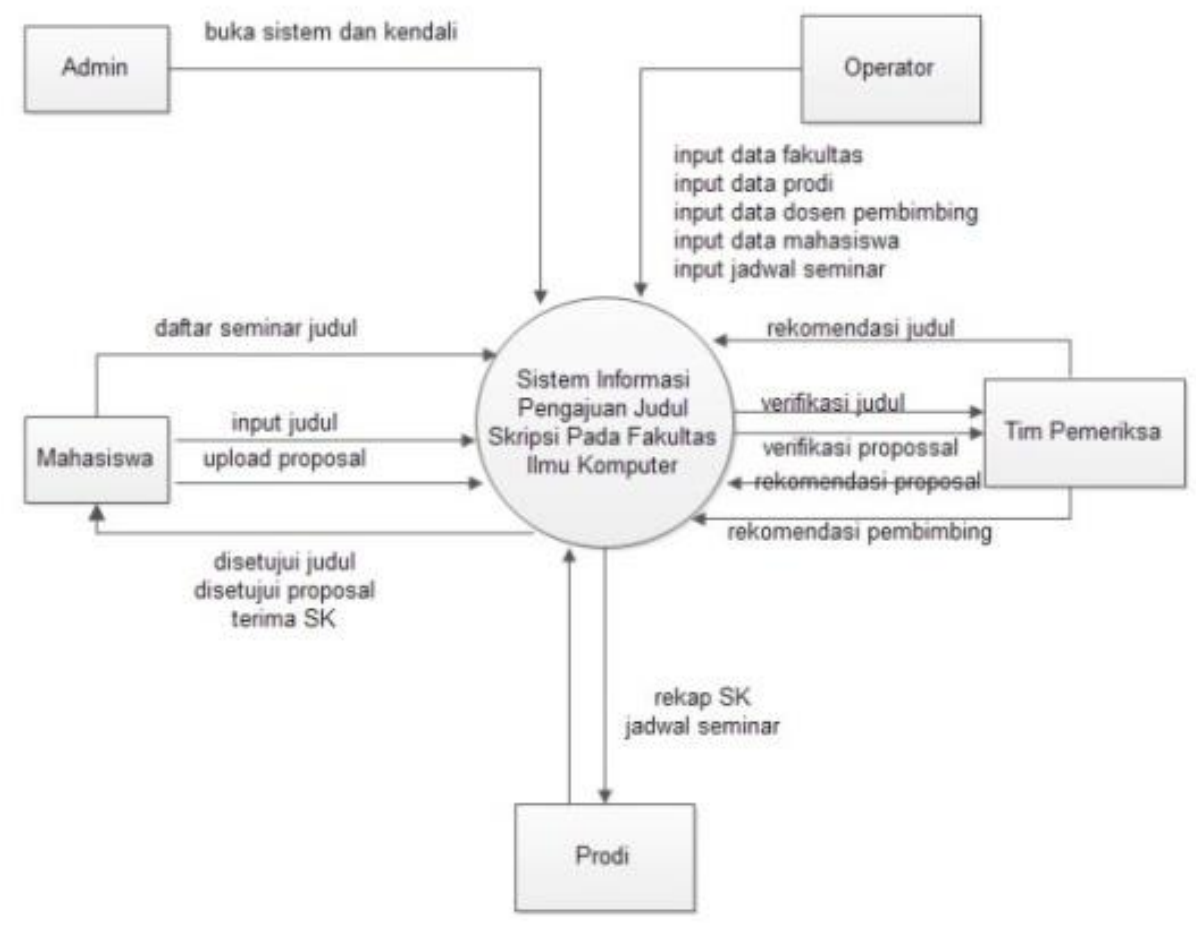

Gambar 1. Kontek Diagram

Diagram konteks merupakan alat untuk analisis struktur. Pendekatan struktur ini untuk menggambarkan sistem secara garis besar atau secara keseluruhan. Diagram konteks yang akan dibuat menghasilkan sumber informasi yang dibutuhkan dan tujuan yang akan dihasilkan.

2. Perancangan Basis Data

Basis Data merupakan kumpulan dari data-data yang saling terkait dan berhubungan satu sama lain. Perancangan basis data merupakan perancangan yang digunakan untuk pembuatan dan penyimpanan data ke dalam sistem terdiri dari beberapa file database. Pada perancangan basis data ini akan dibahas Normalisasi, Entity Relationship Diagram (ERD) dan Struktur File. 


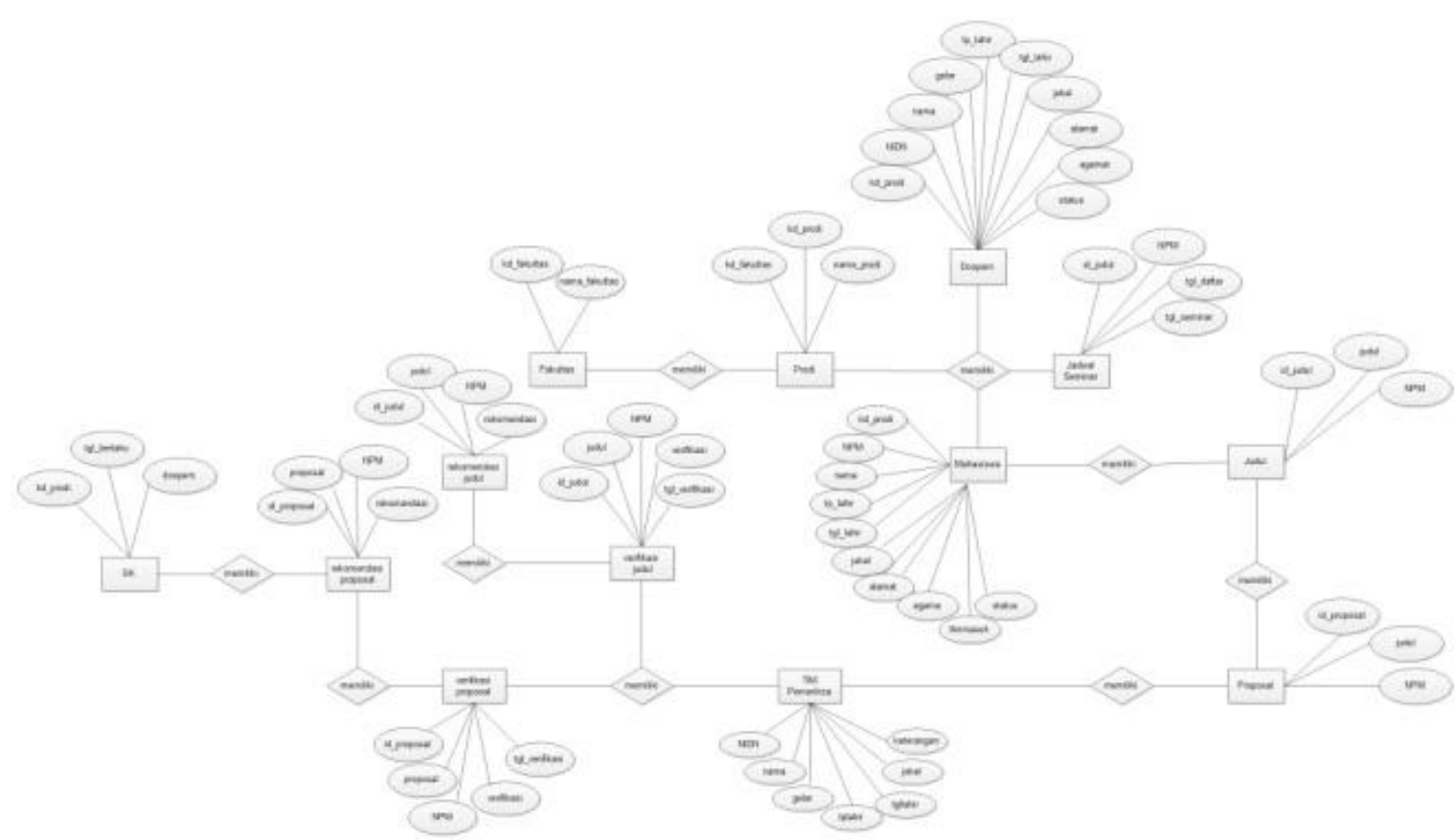

3. Rancangan User Interface

Gambar 2. ERD

a) Form Login

Untuk dapat melakukan proses yang lengkap pada sistem, user diharuskan melakukan proses login terlebih dahulu. Proses login dapat dilakukan jika user sudah memiliki username dan password. Desain fungsi login seperti gambar berikut :

\section{Judul Tugas Akhir}

Enter your username and password

\section{Username}

\section{Password}

\section{Masuk}

\section{Login Forgot Password Signup}

Gambar 3. Form Login 
b) Halaman Utama Admin

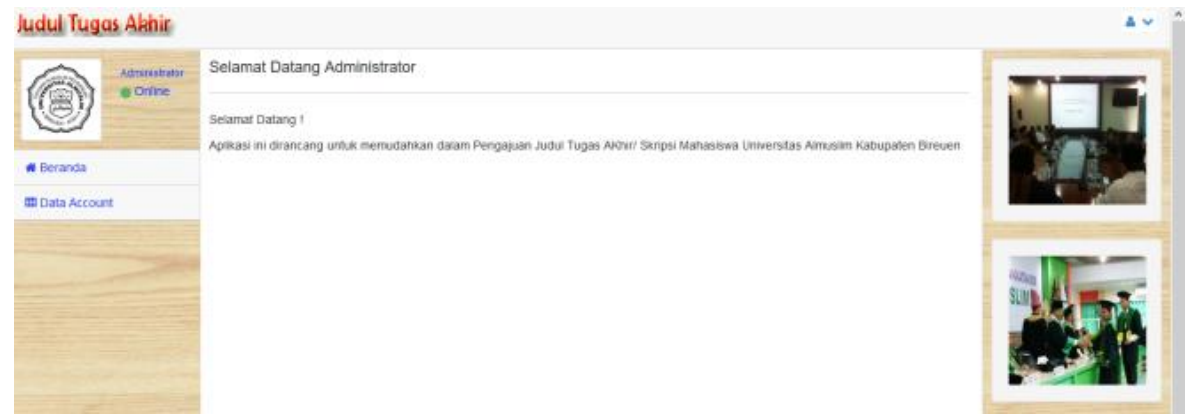

Gambar 4. Halaman Utama Admin

c) Halaman Utama Operator
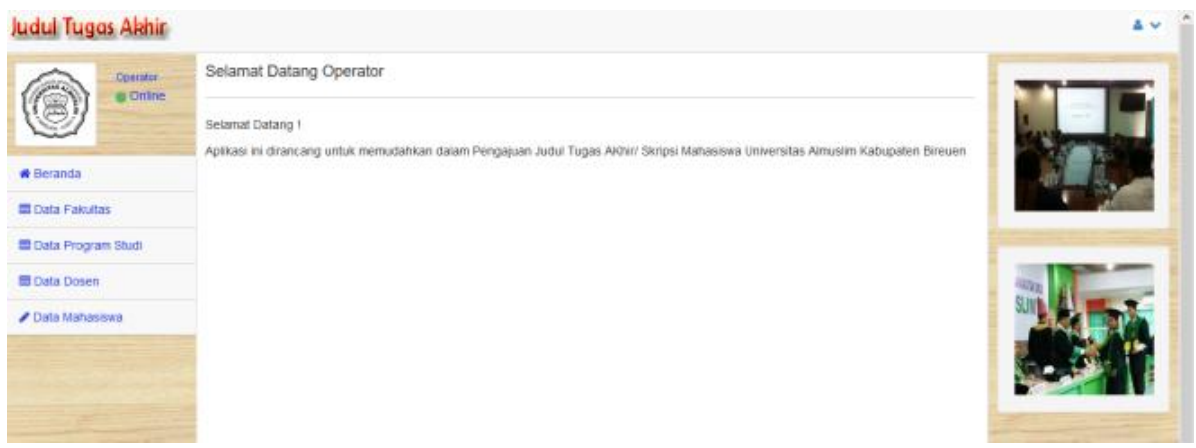

Gambar 5. Halaman Utama Administrator

d) Halaman Utama Mahasiswa

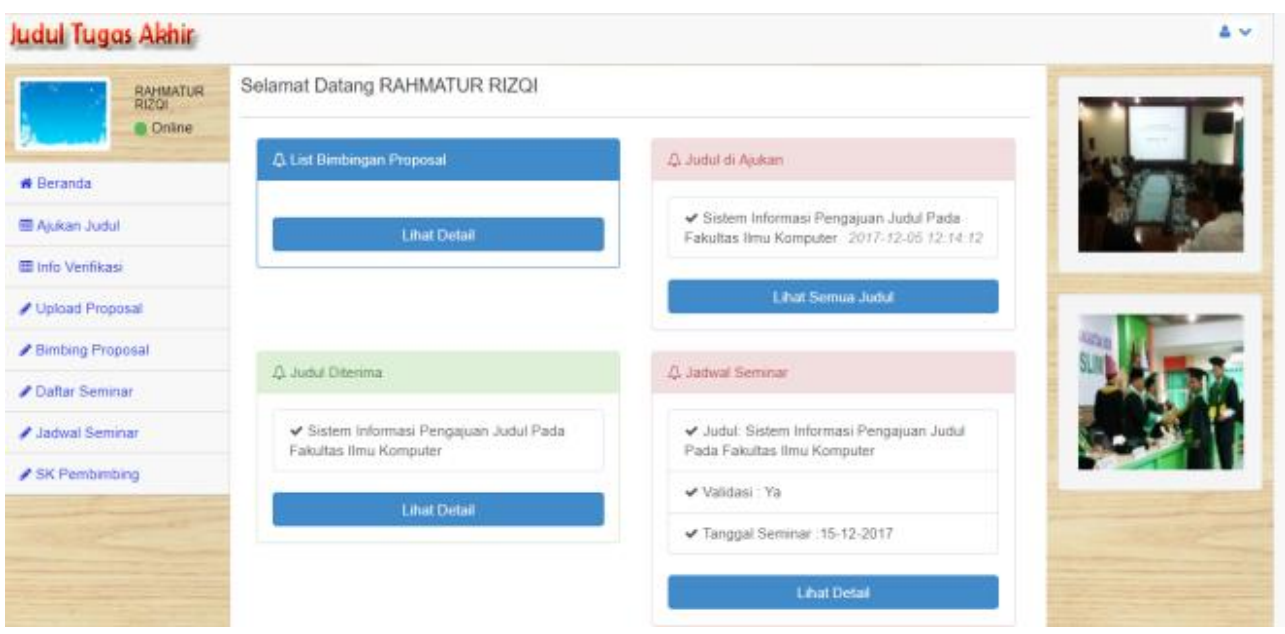

Gambar 6. Halaman Utama Mahasiswa 
e) Halaman Utama Pengajuan Judul

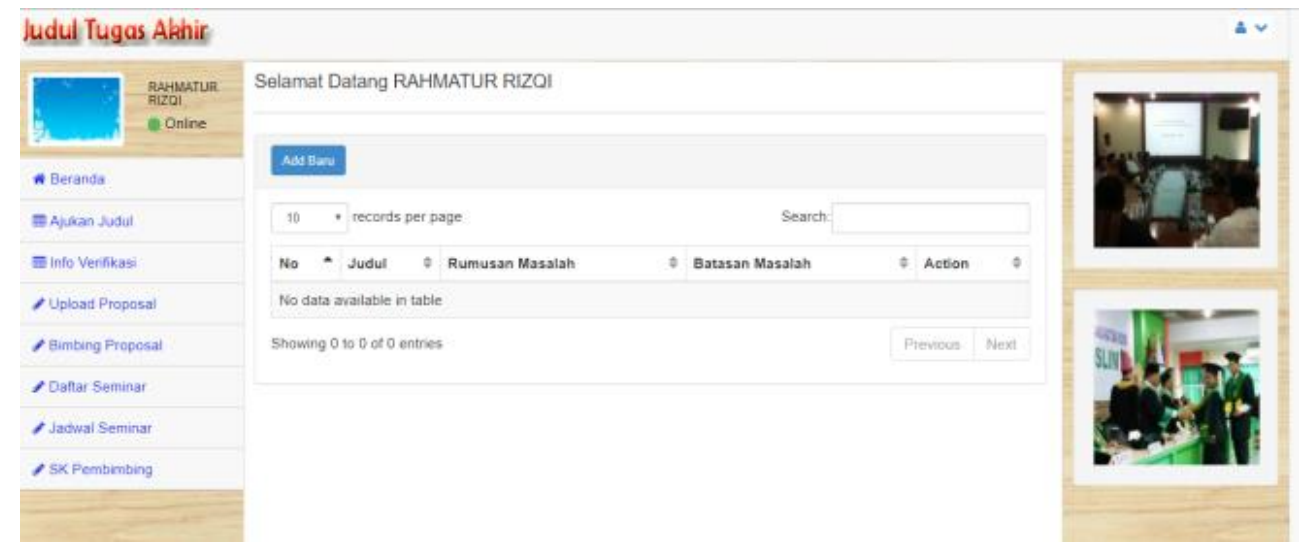

Gambar 7. Halaman Utama pengajuan judul

f) Halaman Utama Info Verifikasi

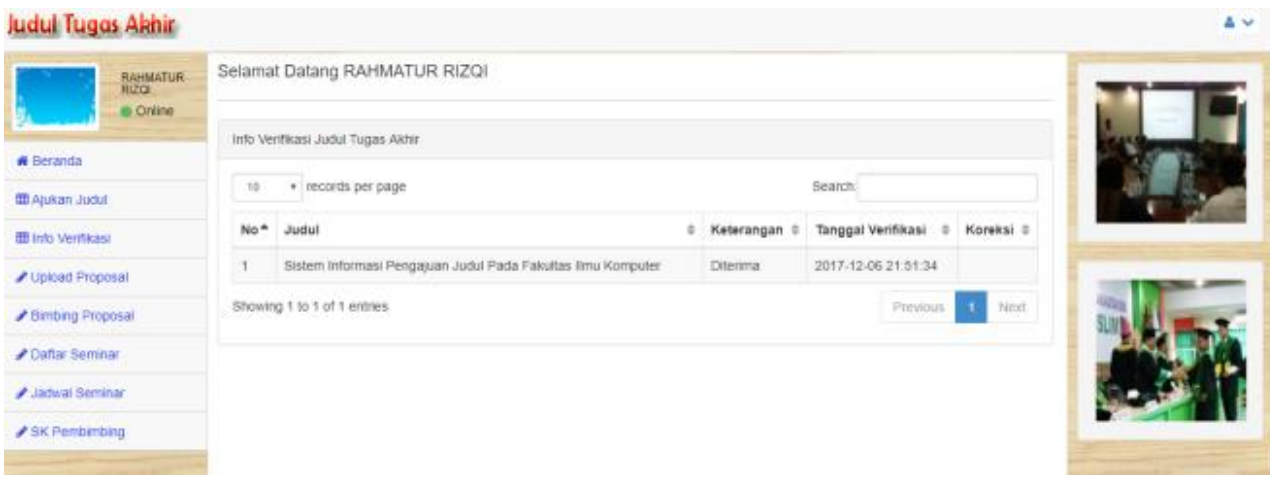

Gambar 8. Halaman Utama info verifikasi

g) Halaman Utama Upload Proposal

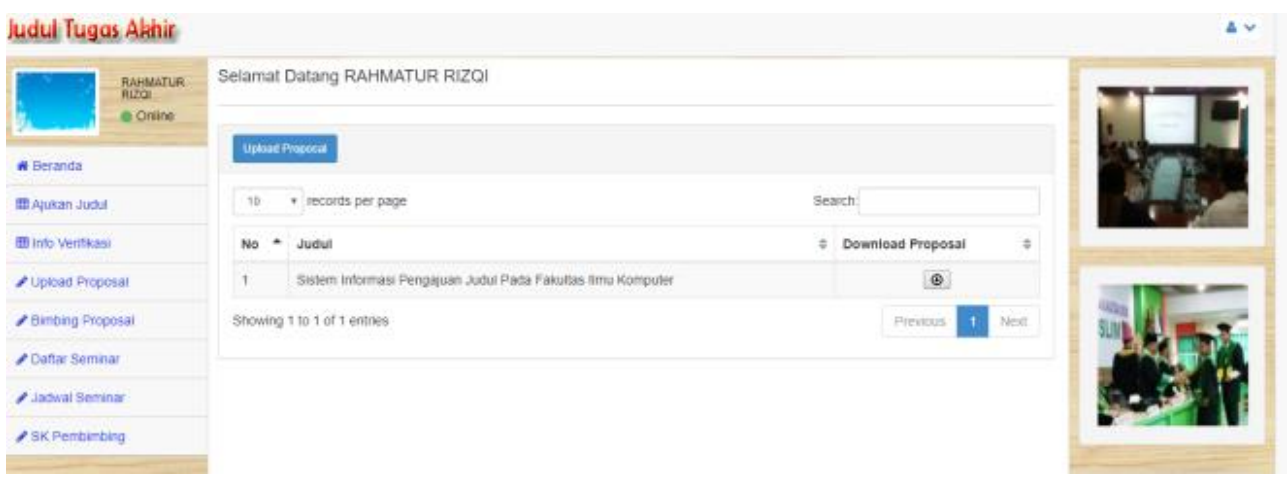

Gambar 9. Halaman Utama upload proposal 
h) Halaman Utama Bimbing Proposal

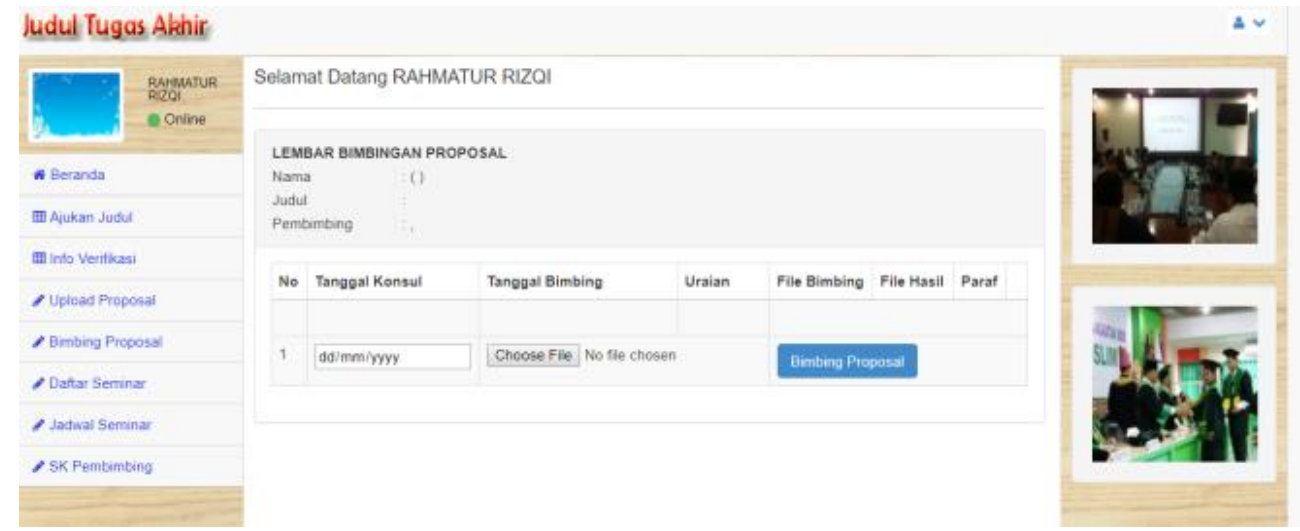

Gambar 10. Halaman Utama bimbing proposal

i) Halaman Utama Daftar Seminar
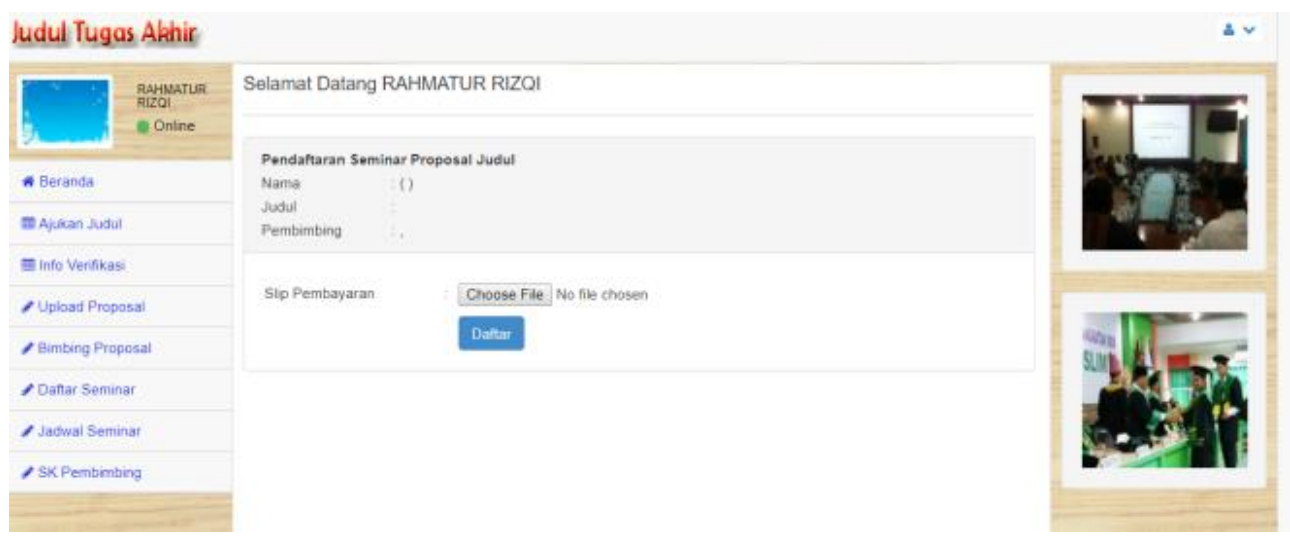

Gambar 11. Halaman Utama daftar seminar

j) Halaman Utama Jadwal Seminar
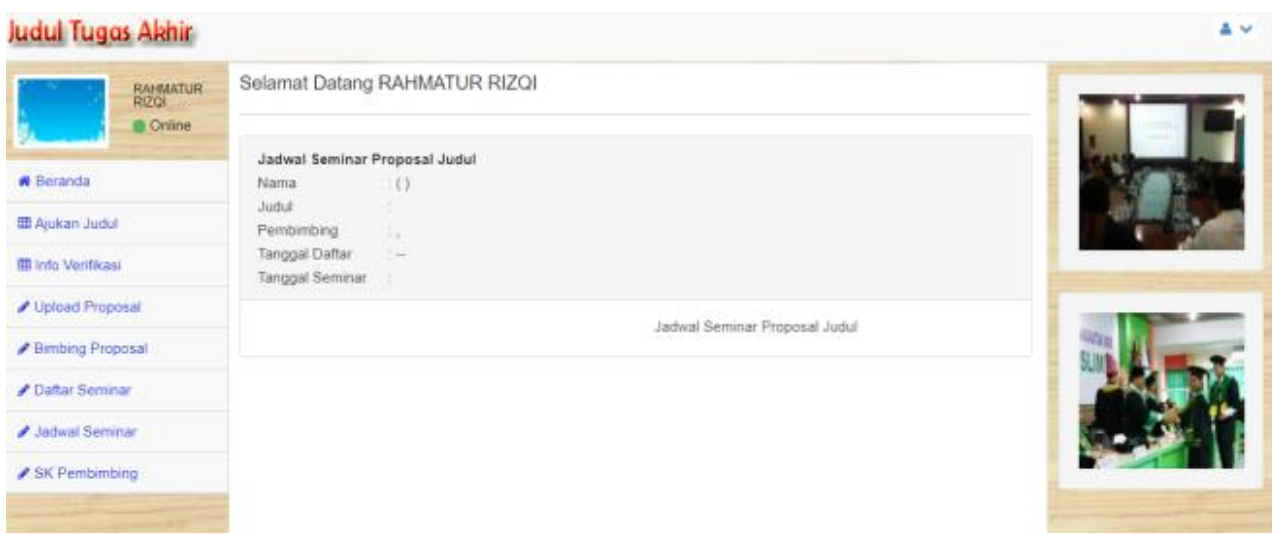

Gambar 12. Halaman Utama jadwal seminar 
k) Halaman Utama SK Pembimbing

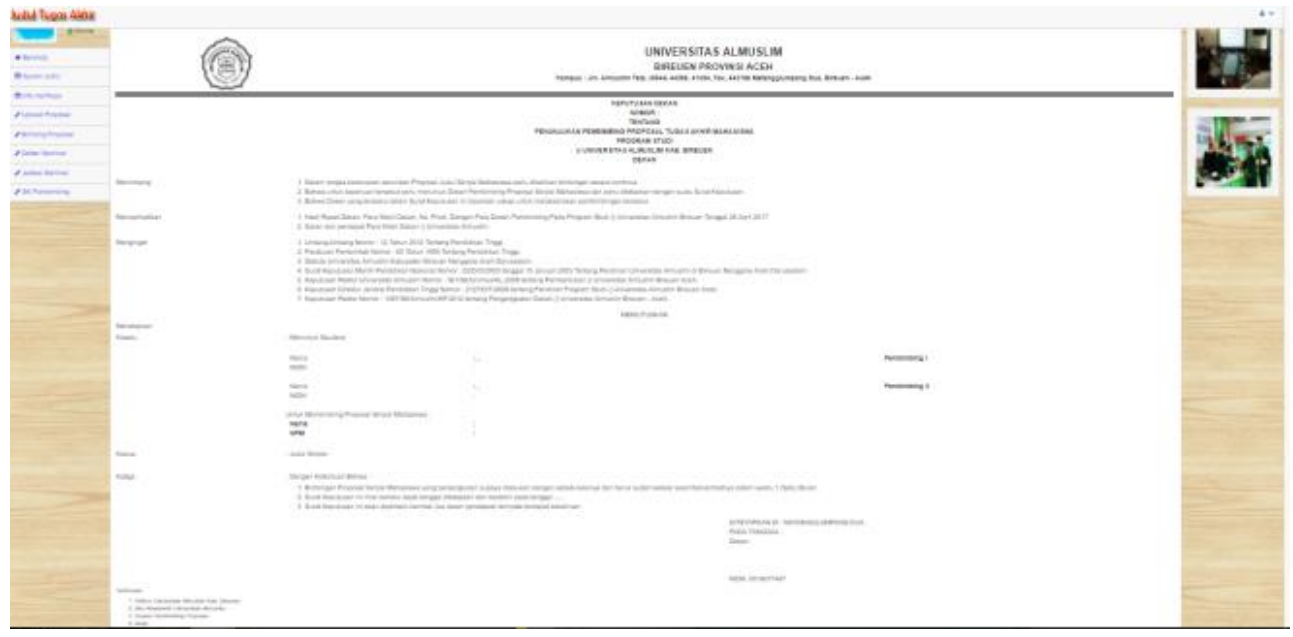

Gambar 13. Halaman Utama SK

\section{Kesimpulan}

Berdasarkan penelitian yang telah dilakukan, maka dapat diambil kesimpulan sebagai berikut :

1. Sistem informasi yang dikembangkan mampu mengakomodir segala keperluan pengajuan skripsi pada Fakultas Ilmu Komputer Universitas Almuslim Bireuen, sehingga mahasiswa tidak perlu lagi melakukan pengajuan judul seara langsung dengan mendatangai kampus.

2. Sistem informasi yang dikembangkan mampu membantu kebijakan penanggulan Covid-19 dikarenakan mampu membatasi bertemunya mahasiswa dengan pihak administrasi kampus secara langsung.

3. Pengembangan yang dapat dilakukan di penelitian berikutnya adalah perluasan sistem yang mampu mengakomodir segala urusan administrasi pada Universitas Almuslim, sehingga mahasiswa tidak perlu lagi datang ke kampus secara langsung untuk keperluan administrasi maupun proses perkuliahan.

\section{Daftar Pustaka}

Fajrillah, F., Sulaiman, O. K., Abi Hamid, M., Simanihuruk, L., Simarmata, J., Hasibuan, M. S., . . Guci, D. A. (2020). MOOC: Platform Pembelajaran Daring di Abad 21: Yayasan Kita Menulis.

Gunawati, R. (2005). Hubungan antara efektivitas komunikasi mahasiswa-dosen pembimbing utama skripsi dengan stres dalam menyusun skripsi pada mahasiswa Program Studi Psikologi Fakultas Kedokteran Universitas Diponegoro. Universitas Diponegoro.

Hapsari, S. A., \& Pamungkas, H. (2019). Pemanfaatan google classroom sebagai media pembelajaran online di universitas dian nuswantoro. WACANA: Jurnal Ilmiah Ilmu Komunikasi, 18(2), 225-233.

Herliandry, L. D., Nurhasanah, N., Suban, M. E., \& Kuswanto, H. (2020). Pembelajaran pada masa pandemi covid-19. JTP-Jurnal Teknologi Pendidikan, 22(1), 65-70.

Livana, P., Suwoso, R. H., Febrianto, T., Kushindarto, D., \& Aziz, F. (2020). Dampak pandemi COVID-19 bagi perekonomian masyarakat desa. Indonesian Journal of Nursing and Health Sciences, 1(1), $37-$ 48.

Nuari, N. (2014). Perancangan Aplikasi Layanan Mobile Informasi Administrasi Akademik Berbasis Android Menggunakan Webservice (Studi Kasus Reg. B Universitas Tanjungpura). JUSTIN (Jurnal Sistem dan Teknologi Informasi), 2(1), 1-6.

Nurkholis, N. (2020). Dampak Pandemi Novel-Corona Virus Disiase (Covid-19) Terhadap Psikologi Dan Pendidikan Serta Kebijakan Pemerintah. Jurnal PGSD, 6(1), 39-49.

Purwanto, A., Pramono, R., Asbari, M., Hyun, C. C., Wijayanti, L. M., \& Putri, R. S. (2020). Studi eksploratif dampak pandemi COVID-19 terhadap proses pembelajaran online di sekolah dasar. EduPsyCouns: Journal of Education, Psychology and Counseling, 2(1), 1-12. 
Rahardja, U., Aini, Q., \& Zuliana, S. R. (2016). Metode Learning Management System (LMS) iDu Untuk Mendukung Kegiatan Belajar Mengajar MIT Pada Perguruan Tinggi Raharja. Cyberpreneurship Innovative and Creative Exact and Social Science, 2(2), 156-172.

Siahaan, M. (2020). Dampak Pandemi Covid-19 Terhadap Dunia Pendidikan. Dampak Pandemi Covid-19 Terhadap Dunia Pendidikan, 20(2).

Suhardi, M., \& Hariawan, R. (2020). PENGGUNAAN LEARNING MANAGEMENT SYSTEM (LMS) DI PERGURUAN TINGGI. JOURNAL TRANSFORMATION OF MANDALIKA (JTM) e-ISSN 27455882, 1(4 Desember), 376-383.

Sulistiyarini, D., \& Sabirin, F. (2018). Analisis Perancangan Sistem Informasi Administrasi Program Studi Pendidikan Teknologi Informasi dan Komunikasi. Jurnal Penelitian dan Pengembangan Sains dan Humaniora, 2(1), 22-29. 